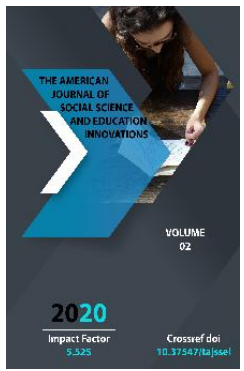

\title{
Multi-Party As The Most Important Condition For The Development Of Democracy In Uzbekistan
}

\author{
Rasulova Nodira Sardarovna \\ Phd In Historical Sciences, Associate Professor Military-Technical Institute Of The National \\ Guard Of The Republic Of Uzbekistan
}

Journal Website:

http://usajournalshub.c

om/index,php/tajssei

Copyright: Original

content from this work

may be used under the

terms of the creative

commons attributes

4.0 licence.

\section{ABSTRACT}

The article analyzes concepts such as a political party, multi-party system, inter-party competition, the positive aspects of the multi-party system, the role of political parties in society, the reasons and factors for the emergence of shortcomings in the activities of political parties in Uzbekistan.

\section{KEYWORDS}

Political party, single-party system, multiparty system, public associations, press body, party charter and program.

\section{INTRODUCTION}

The development of democracy in modern Uzbekistan and the provision of political stability based on the balance of political forces that reflect the interests of different social groups is impossible without political competition and the normal functioning of a multi-party system.

The multi-party system and inter-party competition are one of the most important signs of the formation, inalienable attributes of the rule of law, civil society. In a civil society, pluralism and competition of political influences of various political actors involved in the process of making state decisions necessarily take place.

One of the classic definitions of the party system in modern political science is the definition of the famous French political scientist M. Duverger: "In each country, for a more or less long period, the number of parties, their internal structure, their ideology, their relative sizes, their alliances, their types 
of opposition acquire a certain stability. This stable ensemble forms the system of parties "[1].

Parties arise for many reasons. They appear as a result of certain social differences in society, the emergence of special economic and political interests among certain layers of society. Parties are also formed on the wave of social discontent and opposition to the official authorities.

Thus, a party is a voluntary union of people, bound by an ideological community, seeking to wield political power or to participate in the exercise of power in the state. The party is a stable public organization that seeks to use state power to solve urgent problems in accordance with its ideas and concepts. She seeks to possess such power, at least partially or temporarily.

\section{RESULTS AND DISCUSSION}

A multi-party system is the functioning of several political parties in one country or another, competing with each other and seeking participation in government. And when this or that party fails to enter the government, it is in opposition, criticizes the official authorities, defends its views, as a rule, by constitutional means. In other words, a multiparty system is a kind of coexistence in which each political party seeks to pursue its own line, reckoning, to a certain extent, with common interests [2].

Political ideology is developed and substantiated by representatives of political elites for dissemination among the population. And the more people become adherents of one or another ideology, the more chances this elite has to win political power [3]. Since it is political parties that express certain social interests, rely in their activities on specific social strata and groups, are representatives in the political arena, then one of the central tasks of political parties is to form and establish the aggregate political interest of all layers of society.

M. Duverger noted that the formation of the party is associated with the definition of the social base, the development of program principles, the addition and replenishment of the ranks of fixed members and supporters who feel [4].

$\mathrm{N}$. Lapina writes that various factors influence the activities of political parties. Among them are the following, the most significant external factors:

- political and socio-economic situation in the country;

- the presence of political processes that significantly affect the life of the state and require the participation of certain political forces in them;

- social strata or groups on which a political party relies;

- the presence or absence of an administrative resource;

- support or opposition of the media;

- connections, contacts, support of the population and mass public organizations;

- the mentality of the majority of the country's population, etc. [5].

As you know, parties have a complex internal structure. The following elements are highlighted: the supreme leader and the staff, performing a leading role; a stable bureaucratic apparatus executing the orders of the leadership group; active party members participating in its life, not part of the 
bureaucracy; passive members of the party who adhere to it, only to a small extent participate in its activities. To the listed groups should be added persons who support the party, not being its members - patrons. They may or may not belong to a party.

The system-forming basis of political pluralism is not just the presence of a party system in society, but the inter-party competition of political parties, each of which represents the interests of certain social groups and strata of the population, while the struggle between parties for power (or, more precisely, for their representation in elected bodies power) is only one of the elements of cross-party competition. In democratic countries (for example, the Federal Republic of Germany, France, Italy, Great Britain, etc.), cross-party competition includes:

- the struggle for votes during election campaigns in order to obtain significant representation of the party in parliament or municipal representative bodies (local government);

- the struggle between party factions in parliament and local representative bodies for the adoption of laws and other state decisions that contribute to the practical implementation of party programs and meet the expectations of those social strata and groups whose interests are expressed and defended by the party. One of the key aspects of this struggle is the struggle between the ruling parliamentary majority and the parliamentary opposition;

- the struggle for the formation of a positive image of the party in society and the expansion of the number of supporters and members of parties on this basis.

Parties should keep their finger on the pulse of public opinion. The most effective thing now is direct contracts of the party with its members, increasing its electorate, entering into their interests, problems. "If we approach this issue self-critically (and this is what serious politicians should do), the problem is that the majority of the country's voters do not yet see political parties as a force capable of objectively expressing and consistently, through parliamentary activities, implementing their political interests "[6].

Democracy without a multi-party system is impossible. Moreover, despite the collapse of many parties, in the world as a whole, the prevailing trend is to increase their number and role. Continuing global politicization seems to be the basis of the multiparty system - the involvement of more and more broad layers of the population in politics with an increasing variety of parties.

In Uzbekistan, political power rests on a multiparty system. Today, there are five national parties functioning in the country: the People's Democratic Party of Uzbekistan, the Liberal Democratic Party of Uzbekistan, the Social Democratic Party of Uzbekistan "Adolat", the Democratic Party of Uzbekistan "Milliy Tiklanish", the Ecological Party of Uzbekistan. The presence of a multi-party system forms a more or less competitive environment in the political arena.

The development of pluralistic democracy in the Republic of Uzbekistan is still in its infancy. The political parties of Uzbekistan are just beginning to master the culture of political polemics, modern civilized forms and methods 
of inter-party competition and inter-faction struggle. The state of political pluralism is negatively affected by the absence of fundamental fundamental differences in the statutory and program documents of political parties.

\section{CONCLUSION}

The underdevelopment of political parties in Uzbekistan is partly due to objective reasons, and above all, the weak social structure of society, which has not yet become civil in the true sense of the word.

\section{Main reasons:}

- comparison of programs, declarations of political parties and the objective results of their political activities shows that they are characterized by an insufficient degree of interaction between the theoretical attitudes and practical affairs of the party, there is a huge gap between them;

- age, the composition of party members, as a rule, is above average and therefore enthusiasm, energy, courage (psychological characteristics of a young age) are somewhat reduced;

- parties are not mobile, have little initiative, are still not very popular among young people;

- existing political parties do not have sufficiently clear and deep ties with the groups of society they have chosen as their social support. One of the most important reasons for the amorphousness of the political parties in Uzbekistan is that the processes of identification of social interests, of various social strata of society, their expression and accumulation have just begun.

- The elimination of the above subjective shortcomings will not only allow parties to acquire their recognizable face, their own style in society, but significantly expand their ranks, and in general, the multi-party system of Uzbekistan is further developed.

- $\quad$ An analysis of the pros and cons, assets and liabilities of the domestic multi-party system requires identifying those factors that have shaped its current qualitative state in one way or another. These include the following:

- $\quad$ specific national mentality and the level of political culture of society, associated with the extremely limited experience of political parties at the beginning of the century (1917-1920) and discrediting the very life of the party in the Soviet period;

- $\quad$ the emergence of the parties themselves, not on the basis of the social interests of society, but with the help of initiated actions by the authorities and groups of activists, which determined the subsequent development of these sprouts of democracy;

- the development conditions in which the parties found themselves due to the fact that the state assumed the functions of forming a broad social base for the democratization of society, strengthening political stability, social harmony, the rule of law, laying the foundations of democratic institutions; the peculiarities of our majoritarian electoral system, where parties are deprived of the opportunity to nominate candidates according to their own list, which is the most conducive to the 
consolidation of the party itself, but they

met with the tough resource of the party of khokims - candidates of local authorities, for whom the voters of rural districts of the republic voted especially actively;

- $\quad$ the leading role of the executive branch of power, which in the eyes of society influences the authority of the representative branch, the importance within parliamentary life, the activities of party factions in the Oliy Majlis and local Kengashes [7].

In our opinion, under the political parties of Uzbekistan it is advisable to create information and analytical structures that are engaged in the development of strategic programs, forecasting the political situation, political research, and analysis of state policy.

There is no doubt that the measures being taken today to improve party building, strengthen inter-party competition, increase the role of political parties will become an important factor in the successful advancement of Uzbekistan along the path of democratization and liberalization of political and economic life, reforming civil society, realizing a long-term goal - to become one of the modern developed democracies.

\section{REFERENCES}

1. Duverger M. (2000) Political parties / Per. with French. - Moscow: Academic Project. -538 p.

2. Abdunabiyev A. (1991) Multi-party system - a form of political organization of society. - Tashkent: Uzbekistan. - P. 8.
3. Kotlyarov I.V. (2011) Sociology of political parties / I. V. Kotlyarov. Minsk: Belarusian Science. - 388 p.

4. Duverger M. (1997) Political institutions and constitutional law. Anthology of world political thought: in 5 volumes. V. 2. Foreign political thought. XX century. - Moscow. P.648.

5. Lapina N. (2003) Political parties and prospects of party building in the Samara and Yaroslavl regions / $\mathrm{N}$. Lapina // Economy, politics, power. No. 7. P.115-147.

6. Djumayev R. (1996) The political system of the Republic of Uzbekistan: formation and development. Tashkent. - P. 121.

7. Dubkov V.V. (2008) Theory and practice of building a democratic society in Uzbekistan. - Tashkent. - P. 126. 